\title{
IAMJ
}

INTERNATIONAL

AYURVEDIC

MEDICAL JOURNAL

\section{REVIEW OF ANATOMY AND PHYSIOLOGY OF URINARY SYSTEM W.S.R TO MUTRAVAHA SROTAS}

\author{
$\underline{\text { Shaveta Sawhney }}{ }^{1}, \underline{\text { Lokesh }}^{2}$ \\ ${ }^{1}$ Associate Professor, ${ }^{2} \mathrm{PG}$ scholar; \\ Department of Kriya Sharir, Patanjali Bhartiya Ayurvigyan Evam Anusandhan Sansthan, Haridwar, Uttarakhand, \\ India
}

Corresponding Author: drlucky341@gmail.com

https://doi.org/10.46607/iamj2408092020

(Published online: September 2020)

Open Access

(C) International Ayurvedic Medical Journal, India 2020

Article Received: 08/08/2020 - Peer Reviewed:26/08/2020 - Accepted for Publication: 01/09/2020

(D) Check for updates

\section{ABSTRACT}

The living body or Sharir is the result of aggregation of innumerable structures called as Srotas. Srotas is a structural and functional unit of the body through which substance flow from one part to another part and body get nourishment through Srotas. Acharyas mentioned many Srotas like Pranavaha, Udakvaha, Raktavaha, Mansvaha, Medovaha, Majjavaha,Shukravaha etc. In this row Mutravaha Srotas is one of the most important and functional Srotas. In Ayurvedic classics Acharya Charaka said Moolsthana of Mutravaha Srotas Basti and Vankshana while Acharya Sushruta considered Moolsthana of Mutravaha Srotas Basti and Medra. Acharya Charaka has narrated the concept from physiological point of view whereas Sushruta has given more emphasis on the anatomical aspect of Srotomoola. Mutravaha Srotas is an important Srotas meant for the excretion of waste product from the body as urine. Mutravaha Srotas is initiated from Basti and Vankshana. Knowledge of Ayurveda in this aspect to provide the better understanding about the urinary system

Keywords: Srotas, Mutravaha Srotas, Urinary System, Basti.

\section{INTRODUCTION}


Ayurveda is a science of life developed by ancient Ayurvedic Acharyas about 5000 years ago with the aim to maintain the health of a healthy person and providing relief to persons suffering from one disease or the other. Detailed knowledge of normal human body i.e. Sharira, is considered helpful in understanding the factors influencing the health. The anatomical, physiological as well as pathological concepts about Srotas are broadly mentioned in Ayurvedic Samhitas. The living body is the resultant of aggregation of innumerable structures called as 'Srotas ${ }^{\text {'[I] }}$. According to various Acharyas. Srotas are the channels responsible for the nourishment of the body. Srotas are derivatives or modification of the PanchaMahäbhütas especially Akash Mahābhüta. Enumeration of Srotas is also opined by different Acharyas Srotas have their own Moolsthanas as the root of origin. In the context of 13 different types of Srotas which are mentioned in our classics, Mutravaha Srotas is one among the most fundamental element of urinary tract. Acharaya Sushrut has mentioned two Moolsthanas of Mutravaha Srotas i.e. Basti (urinary bladder) and Medra (Urethra) ${ }^{[2]}$ while Acharya Charaka considered Basti and Vankshana as Moolsthanas of MutravahaSrotas ${ }^{[3]}$. The Moolsthana is the place of origin i.e. place from where a particular Srotas gets the nutrition and is the controlling center of that particular Srotas ${ }^{[4]}$. In case of Mutravaha Srotas it has been said that since Basti and Vankshan are associated with Mutra Utpatti so they should be considered as root organs. In the context of Malavaha Srotas among the two Srotomool described by our Acharyas, one Moola serves as the controlling station and the other Moola carries the function of excretion. ${ }^{[5]}$

Table 1

\begin{tabular}{|l|l|l|}
\hline Srotas & Origin Place & Excretion Place \\
\hline Mutravaha Srotas & Basti & Medhra \\
\hline Purishvaha Srotas & Pakvaashya & Guda \\
\hline Swedvaha Srotas & Meda & Lomakupa \\
\hline
\end{tabular}

\section{1) Basti (Urinary Bladder)}

The word Basti means 'to cover', 'base', 'store house' and 'reservoir'. This organ acts as reservoir of urine situated in the Kati Pradesha or below the Nabhi. Acharya Sharangdhar opines that Basti is situated below the Pakvaashya. Basti is one among the Kosthangas $^{[6]}$, Trimarmas, and Pranaaytana.

Synonyms-Malaadhar, Mootraashaya, Mootradhara, Mootraputa.

Structure- Alaaboo Aakaar (Bottle gourd shaped) and Dhanuvakra Aakaar. Acharya Sushruta opines that Basti is fixed on all sides by Sira and Snayu. He further mentioned that Basti is Adhomukha i.e. its outlet is directed downwards and is connected to urethra. ${ }^{[7]}$ In some books like Madhukosha Teeka, the word Basti is used also to indicate the entire urinary tract including kidney, ureter, bladder, urethra etc.

Function-Dhaarana and Poshana of Mutra. The Dhaarana and Poshana of Mootra is regulated by the Apaana Vata. Hence any vitiation in the Apaana Vata alters the function of Basti and leads to different disorders of Basti or Mootravaha Srotas. ${ }^{[8]}$

Embryological Development - During fetal life, Bas$t i$ is derived from the maternal contribution or MaatrujaBhaava.

2) Vrikka (Kidney)

The word Vrikka is derived from the root word "Vrikkadane" which means to take.

Location - Vrikka are two in number and are situated in the lumbar region on either side in the posterior abdominal wall in "Kostha". During fetal life Vrikka is derived from the maternal contribution or MaatrujaBhaava and is considered as the essence of "Rakta" and "Meda"[9].

3) Gavini (Ureter)

Function - In Atharavveda it is explained that Gavini receives Mutra from the Antras and transport it further to the Mutraashaya ${ }^{[10]}$.

Gavini (Ureters) are pair of thick-walled tubes made up of smooth muscle that propel urine from the kidney 
to urinary bladder. Each ureter is 10 to 12-inch-long and urine flow partly down by gravity.

\section{4) Mutraprasek}

Mutraprasek signifies the urethra, mainly its penile part.

Synonyms- Mutraputak, Mutramarga, Mutrasrotas. Length-2 Angulas in Female; 12 Angulas in Male.

Function - In male Mutraprasek performs the function of transporting both Mutra and Shukra while in female it is responsible for the transport of Mutra only.

\section{5) Mutravaha Nadi}

Location - Acharya Sushruta explained that Mutravaha Nadi is situated in between the Amaashya, Pakvaashya and Basti.

Structure - These Nadis have thousands of minute openings which are not visible to the naked eye.

Function - Mutravaha Nadi vessels arising from large intestine which fill the urinary bladder like rivers feed water to ocean on earth.

Same description is available in Ashtang Hridaya in the name of MutravahaSira as it is said that these Nadis are the minute channels which carry Mutra to Basti. These Siras / Nadis are the openings on the lateral side of Basti and are responsible for the filling of Basti with Mutra continuously by the process of Nisyandan ${ }^{[11]}$.

6) Vankshana- Acharya Charaka consider the Moolsthana of MutravahaSrotas as Basti and Vankshana. In present era Basti is more relevant to urinary bladder. While the Vankshana is relevant to the Lumbosacral region. Vankshana is also related to Vrik$k a \mathrm{But}$, in reference to Vrikka with Gavini, it is more appropriate to consider Vankshanas the whole urinary system. ${ }^{[12]}$

Physiological Aspects of MutravahaSrotas in the Formation of Urine

First description about formation of urine is present in 'Atharvaveda' in there it is clearly mention that Mutra nirman (urine formation) takes place in Antras (alimentary canal ) and it is transferred through Gavini (ureters)and reaches Basti (bladder). ${ }^{[13]}$ In Ayurvedic Physiology, the phenomena of Urine Formation starts right from the process of Digestion of food, differenti- ation of Prasada and KittaBhaga, absorption of Prasada Bhaga; especially absorption of liquid part from the Pakvaashya (Large intestine) and gets into circulation. This absorbed liquid part reaches up to Nephron of kidney by Adhogami Dhamnis (arteries of urinary system) Acharya Dalhana states that the main Mutravaha Dhamnis are two in number and they are further divided into enumerable branches ${ }^{[14]}$. After filtration (Nisyandana) in the Nephron of the kidney the outcome (Mutra/urine) gets collected in the Basti and then passed out that urine by Mutrapraseka.

\section{DISCUSSION AND CONCLUSION}

In few words it can be summarized that the Mutravaha Srotas is one of the most important system of human body. As per Acharya Charaka a physician who knows anatomical and physiological details of body who has perception to predict about past, present and future of the disease is helpful to understand the factors influencing health and therefore such knowledge is widely appreciated by experts. It is impossible to treat any kind of disease effectively without the deep knowledge of Sharir Rachana and Sharir Kriya but by the time it is fade up due to lack of research and references. From the above available references, it can be understood that in the ancient Ayurvedic literature the concept of urinary system as an independent unit has been accepted. The detailed anatomical and physiological vision of Ayurveda in this regard is important without which the better understanding about the treatment part can't be developed. So that the disease of this system can be understood with more clarity and treated accordingly.

\section{REFERENCES}

1. Vd. Harish Chandra Singh Kushwaha. Charaka Samhita with commentary of Chakrapaanidatta part 1:Sutrasthana.Reprint Edition 2016. Varanasi: Chaukhambha Orientalia; Page No. 629.

2. Dr. Bhasker Govind Ghanekar. Sushurta Samhita: Sharirsthana. Reprint Edition 2013.New Delhi: Meherchand Lachaman Das Publications; Page No. 242.

3. Vd. Harish Chandra Singh Kushwaha. Charaka Samhita: Sutrasthana. Reprint Edition 2016. Varanasi: Chaukhambha Orientalia; Page No. 631. 
4. Anil Avhad, Manjiri Walinjkar, R.R. Dwivedi, H.A. Vyas. Assesment and Evaluation of Srotomula: Prabhavasthana (Place of Origin/Nutrition), Niyantraka Sthana. Journal of Indian System of Medicine.2015; vol3(4), pp 197-202.

5. Anil Avhad, Manjiri Walinjkar, R.R. Dwivedi, H.A. Vyas. Assessment and Evaluation of Srotomula: Comparison of the Views.Journal of Indian System of Medicine.2015; vol3(4), pp 197-202.

6. Dr. Brahmanand Tripathi. Sarngadhara Samhita: Purvakhand. Reprint Edition 2017. Varanasi: Chaukambha Surbharti Prakashana. Page No. 39.

7. Dr. Keval Krishna Thakral, Sushruta Samhita with commentary of Dalhana and Gayadas part 1: Nidansthana. Reprint Edition 2016. Varanasi: Chaukambha Orientalia; 2014. Page No. 734.

8. Kaviraj Atrideva Gupta. Astanga Samgraha with hindi commentary part 1: Sutrasthana. Reprint Edition 2016. Varanasi: Chowkhamba Krishandas Academy. Page no. 160 .

9. Dr. Brahmanand Tripathi.Sarngadhara Samhita: Purvakhand. Reprint Edition 2017. Varanasi:Chaukambha Surbharti Prakashana. Page No. 47.

10. Acharya Om Prakash Verma, Atharvaveda Samhita: 1/1/3, Vedic pragyaprakashan Saharanpur, Page 29.

11. Dr. Keval Krishna Thakral, Sushruta Samhita with commentary of Dalhana and Gayadas part 1: Nidansthana. Reprint Edition 2016. Varanasi: C haukambha Orientalia; 2014.Page No. 734.

12. Dr. Sushma Baretiya and Dr. Dinesh Choudhari. Anatomical Concept of Mutravaha Srotas in Present Era: Discussion and Conclusion. World Journal of Pharmaceutical and Medical Research.2018,4(3), 318-320.

13. Acharya Om Prakash Verma, Atharvaveda Samhita: 1/1/3, Vedic pragyaprakashan Saharanpur, Page 29.

14. Dr. Keval Krishna Thakral, Sushruta Samhita with commentary of Dalhana and gayadas part 1: Nidansthana. Reprint Edition 2016. Varanasi: Chaukambha Orientalia; 2014.Page No. 735

\section{Source of Support: Nil \\ Conflict of Interest: None Declared}

How to cite this URL: Shaveta Sawhney \& Lokesh: Review Of Anatomy And Physiology Of Urinary System W.S.R To Mutravaha Srotas. International Ayurvedic Medical Journal \{online\} 2020 \{cited September, 2020\} Available from: http://www.iamj.in/posts/images/upload/4452 4455.pdf 